\title{
Applying Green Practices in Hotels Sector to Ensure Sustainable Development- Case Study of The Hotels in Siwa Oasis
}

\author{
Aya S.A. Salem
}

\begin{abstract}
Hotel sector is one of the most important factors affecting pollution globally, so the adoption of green practices (environmentally friendly practices) in that sector had a direct impact on sustainable development issues. Therefore, this research aims to present an overall approach to highlight, evaluate the green practices in Siwa hotels and their relationship to sustainable development.

The data was collected by a questionnaire form by personal interview with hotel managers including 11 hotel intentionally selected who do green practices only out of total 20 hotel in Siwa Oasis. In addition to hotel case study and photographing.

The Results shows significant correlation between green energy practices as a dependent variable and between the total number of hotel stars and ISO certificates only as independent variables at a significant level of 0.05 and the most positive results for Taziry Ecolodge hotel. These results support the application of green practices systems in the hotel sector to ensure sustainable development in water resources, energy, solid waste and food.
\end{abstract}

Keywords: Green practices - sustainable development - hotel sector - siwa oasis.

\section{INTRODUCTION}

Environment and tourism are two related elements, which represent the basic pillars that must be known in sustainable development, (Norazah, 2015).

There are many types of tourism and their patterns vary according to the motives that constitute a major attraction for tourism. Among the types of tourism: medical, sports, religious, archaeological and other types, in addition to the emergence of other new types that have emerged as a result of the rise in living standards and the availability of leisure time such as safari tourism, conference tourism, ecotourism, scientific tourism, recreational tourism, (Sameh A., 2013).

The distinctive location of Siwa Oasis and the natural and human phenomena it contains have led to the great diversity in the tourism environment for it, which led to the diversity of the tourist patterns in the oasis, as it has many attractions that qualify it to be a tourist destination for many types of tourism, such as ecotourism, historical and archaeological tourism, Safari tourism, medical tourism, (El demerdash, A., 2018).

Siwa Oasis is considered to be the city and district of Siwa. It is located in the western desert, $800 \mathrm{~km}$ from Cairo the capital, and $300 \mathrm{~km}$ from Matrouh city, the capital of the Governorate, (Barakat, M. , 2016).

Siwa is considered one of the most important tourist attractions on a global level. This is mainly because of its characteristic properties both in the natural and human aspects, which serve as a tourism attracting activity. Its natural resources together with the archaeological and cultural heritage provide the opportunity to expand and diversify the existing range of activities and attractions on offer, but at the moment few visitors really appreciate this full range of attractions, (Sameh A., 2013).

Hotels and resorts are among the most important aspects of tourism development, and they need a huge infrastructure which leads to the depletion of the sources of the natural environment or affecting the architectural character of the place, (Neeti K., 2015). Hence entrance the environmental represents the correct intellectual framework for the development of tourist agglomerations, starting with choosing the appropriate development pattern and down to the method of planning and designing the tourist complexes, (El demerdash, A., 2018). And it is necessary to develop an integrated system of policies and practices that do not only include hotel management and employees, but also all concerned with environmental protection and sustainability and to reassessment, review, local and national training policies, (Erdogan, N. ,2007)

Zwena, B. F. (2009) emphasized that Green hotels are one of the approaches to achieve sustainable development .As he provided examples of environmental hotels in the world and presented some sound environmental practices that environmental hotels can follow and criteria for evaluating any resort or environmental hotel.

Given the importance of the hotel sector and its impact on the environment, most of the hotels around the world have recently adopted the slogan "green hotels". This is one of the recent trends in Eco-tourism. Therefore, the sustainable tourism approach has become

DOI: $10.21608 /$ asejaiqjsae.2021.170151

${ }^{1}$ Family affairs and Institutions Management Home economics Department

- Faculty of AgricultureAlexandria University

Email: aya.ahmed@alexu.edu.eg

Received April 05, 2021, Accepted, May 11, 2021. 
a method many of the global tourism enterprises are dependent on. Contrary to what many may believe, the application of the concept of sustainable tourism is not costly in financial terms; in fact, it may be the cause of both moral and material profit which in and of itself will profit tourism organizations, (Hamad, A. E. ,2015).

And this is what (Raslan, A. A. and others, 2016) did in their study about evaluation for sustainable development in hotels in some tourist areas in Egypt, which aimed to explore the concept of sustainable development (SD) and the importance of its practices in Egyptian hotels (Cairo, Alexandria and Hurghada), they provided the hoteliers with a checklist that can be used to assess their current situations. IPA model provides hotel managers with useful recommendations.

While (Ijasan, K. and others ,2016) pointed out in his study to determine the extent to which greenness affects consumers in South Africa that respondents have a positive attitude towards 'green hotels' but there is a dearth of knowledge as to what standards there are regarding what makes a hotel 'green'.

And as Green or eco-friendly practices in the accommodation sector are growing around the world. Conscious customers demand these services, (Leal Londono M. P. \& Hernandez-Maskivker G., 2016). From here emerges the research problem, which revolves around the extent of the commitment of these hotels to practices, friendly to the environment, especially since tourism represents the main pillar of the national income and the impact of this on sustainable tourism in the study area.

So there were some questions: How well do the hotels in Siwa do green practices?

\section{Research objectives:}

The main objective of this research is to present an overall approach to highlight, evaluate the green practices in Siwa hotels and their relationship to sustainable development.

This goal can be achieved through the following sub-goals:

1-Measuring awareness of applying green practices in hotels.

2-Studying green practices applications in hotels related to some environmental resources including (watersolid waste - energy - sustainable food and beverage).

3-Measure motives for applying green practices in hotels.

4-Recognition benefits and obstacles of applying green practices in hotels.

5-Studying the statistical relationships between research variables.

\section{Applied importance of the research}

These results may benefit the hotel industry involved in green initiatives and activities in formulating effective marketing strategies, uphold aspects of energy efficiency, natural resources and environment and indoor environmental quality in business operations in a sustainable manner besides focusing on maximizing profit.

And Green practices are key to the long-term success of the hotels sector As there is an increasing awareness among those responsible for the hotel industry in the world of the importance of good practices towards the environment and society at large with regard to this sector, because of its benefits in particular to the environment and society in general.

So There is no doubt that practices that take into account the environment and society have a positive impact in terms of reducing costs, gaining a good reputation, and ensuring the site's attractiveness to travelers in the long run.

\section{MATERIALS AND METHODS}

\section{Scientific terms and procedural definitions:}

-Green practices: using non-conventional methods and seek to reduce the negative impact on the environment (Han et al., 2010). According to Green Hotel Association (2009), a green hotel or ecofriendly hotel is a lodging property that incorporates and follows environmentally sound programs and practices such as energy and water saving, waste reduction, recycling in support for the protection of our environment and reduces operational costs. In contrast to the conventional hotel that causes greater harm to the environment by excessive consumption of the scarce resources (i.e. water, energy, and soil), green hotels voluntarily follow the environmental standards and guidelines and incorporate sustainability in their decision making (Han \& Kim, 2010; Manaktola and Jauhari, 2007).

-Sustainable development: conserving resources for future generations and its overall goal is the long term stability of the economy and environment through the integration acknowledgment of economic, environmental and social concerns, (cerin, 2006). And we refer to it in this research to green practices for resources water, energy, solid wastes and food.

Methodology: the researcher used the descriptive analytical method, which depends on describing the phenomenon under study and analyzing its data.

Time limits of the study: The study was done in April 2019 and the research was accepted for publication at a 
conference in the United States of America, but it was canceled due to the Corona pandemic.

Research variables: dependent variables represented in green practices applications in hotels related to some environmental resources including (water- solid waste energy - sustainable food and beverage) while independent variables represented in characteristics of hotel under study.

Research hypotheses: The hypotheses are put in their null state which indicates that there is no relationship between dependent and independent factors.

First hypotheses: "There is no significant correlation between awareness and green practices applications in hotels related to some environmental resources including (water- solid waste - energy sustainable food and beverage) and characteristics of hotels under study".

Second hypotheses: "There is no influence relation between awareness and green practices applications in hotels related to some environmental resources including (water- solid waste - energy - sustainable food and beverage) and characteristics of hotels under study".

Data collection tool: the current research adopted a quantitative approach using the questionnaire as a method for data collection to answer the research question and achieve the aim and objectives. In addition to hotel case study and photographing.

Sample study: the target population of the study was the hotel managers. The researcher contacted with each hotel in the sample and asked to meet the manager or his assistant and explained the broad lines of the research and its importance.

From a total number of 20 hotel in siwa, only 11 were intentionally selected and 9 were not included as they did not apply green practices at all, so they were excluded.

Questionnaire axes: the designed questionnaire involved ten parts:

1-The first part aimed to collect data about the hotel under study, it included several variables:

-Name of the hotel.

-Establishment year: it ranged between 5-23 with mean and standard deviation $14 \pm 6.403$ and they were divided into three categories ( $<8$ years), $(8-<20$ years) and ( $\geq 20$ years).

-Obtaining certificates: (Obtaining environmental management certificates- ISO certificates- other certificates).

-Number of employees: it ranged between 3-45 with mean and standard deviation $12.5 \pm 13.1$ and they were divided into three categories: (From 1-5), (From 6-10) and (11 and more).

-The presence of an environmental consultant.

-Having a quality officer.

2-Second part was about awareness of applying green practices in hotels: It was measured in the light of 23 sentences as Green practices help reduce hotel operating costs and gives the hotel good reputation, whether yes ( 3 grades) or I don't know ( 2 grades) or no (one grade) for positive sentences (18 sentences) and vice versa for the negative sentences (5 sentences). The total scores for the sentences were estimated to determine the degree of awareness of green practices with mean and standard deviation $57.20 \pm 6.03$ and they were divided into three categories: Low ( $<51$ degree), Fair (from 51- <63) and High $(\geq 63)$.

3-Third part was about green practices applications in hotels related to some environmental resources including:

- Water green practices: It was measured in the light of 27 sentences as Treated water is used to irrigate the green areas of the hotel and There is a system for storing rain water, whether always (3 grades) or sometimes ( 2 grades) or rarely (one grade) for positive sentences (24 sentence) and vice versa for the negative sentences ( 3 sentences). The total scores for the sentences were estimated to determine the level of water green practices with mean and standard deviation $82.2 \pm 10.6$ and they were divided into three categories: Low $(<72)$, Fair (from 72- < 93) and High ( $\geq 93)$.

- Solid waste green practices: It was measured in the light of 14 sentence as the hotel helps convert kitchen waste into organic fertilizers and using biodegradable plastic bags and refillable shampoo dispenser, whether always ( 3 grades) or sometimes (2 grades) or rarely (one grade) for positive sentences (14 sentence). The total scores for the sentences were estimated to determine the level of green practices for solid waste and waste with mean and standard deviation $25.5 \pm 5.6$ and they were divided into three categories: Low $(<20)$, Fair (from $20-<31)$ and High $(\geq 31)$.

-Energy green practices: It was measured in the light of 16 sentence as the hotel uses efficient lighting and automatic energy management systems in the rooms like key card, whether always (3 grades) or sometimes (2 grades) or rarely (one grade) for positive sentences (16 sentence). The total scores for the sentences were estimated to determine the level of green energy practices with mean and standard deviation $28 \pm 7.9$ and they were divided 
into three categories: Low ( $<20$ ), Fair (from 20$<36)$ and High $(\geq 36)$.

-Sustainable food and beverage practices: It was measured in the light of 4 sentences as organic food and drinks are used, whether always ( 3 grades) or sometimes ( 2 grades) or rarely (one grade) for positive sentences ( 4 sentences). The total scores for the sentences were estimated to determine the level of sustainable food and beverage practices with mean and standard deviation $9 \pm 2.9$ and they were divided into three categories: Low $(<6)$, Fair (from 6- $<12$ ) and High $(\geq 12)$.

4-Fourth part was about motives for applying green practices in hotels: The number of motives (10 sentences) was calculated with mean and standard deviation $3.9 \pm 2.3$ and they were divided into three categories: Few ( $<2$ motives), Fair (from 2- $<6$ motives) and many ( $\geq 6$ motives).

5-Fifth part was about benefits and obstacles of applying green practices in hotels: the number of benefits (12 sentences) was calculated with mean and standard deviation $6.1 \pm 3.3$. While the number of obstacles (11 sentences) was calculated with mean and standard deviation $3.7 \pm 3.9$ and they were divided into three categories: Few (1-4 obstacle), Fair (from 5-8 obstacles) and many ( $\geq 9)$.

Statistical analysis: mixed methods of data analysis were performed. The collected data were processed and analyzed through some statistical tests using SPSS (ver.22) as arithmetic mean, percentages, simple correlation coefficient and multiple regression function.

\section{RESULTS AND DISCUSSION}

First: General characteristics of the hotel:
Results in table (1) indicate that about half of the hotels $(45.5 \%)$ were built in the period from $8-<20$ years ago, all of them $(100 \%)$ did not obtain environmental management certificates and only one hotel obtained ISO certificates, and this may be one of the reasons for the lack of green practices in hotels under study.

With regard to the number of employees, the majority (72.8\%) ranged from $1-10$ employee. Only two hotels $(18.2 \%)$ had an environmental consultant and a quality officer.

\section{Second: Level of awareness of green practices the impact of tourism on the environment:}

Total level of awareness was distributed among three categories according to the mean and standard deviation. Table (2) shows that more than three quarters of the hotels were low and fair $45.5 \%, 36.3$ respectively, and only $18.2 \%$ fell in the high level.

This may be due to that the Ministry of Tourism does not insist that these institutions must follow green practices. Therefore, attention must be paid to develop the level of hotel managers regarding awareness of green practices.

Third: Green practices applications in hotels related to some environmental resources including:

\section{Water green practices:}

Total level of water green practices was distributed among three categories according to the mean and standard deviation. Table (3) shows that more than half of the hotels were fair $(63.6 \%)$, while only $27.3 \%$ fell in the high level.

Table 1. Distribution of respondents according to the general characteristics of the hotel

\begin{tabular}{|c|c|c|c|c|c|}
\hline General characteristics items & $\begin{array}{c}\text { No } \\
\mathrm{N}=11 \\
\end{array}$ & $\%$ & General characteristics items & $\begin{array}{c}\text { No } \\
\mathrm{N}=11 \\
\end{array}$ & $\%$ \\
\hline 1-Establishment year: & & & 5-Number of employees: & & \\
\hline$<8$ years & 2 & 18.2 & From $1-5$ & 4 & 36.4 \\
\hline $8-<20$ years & 5 & 45.5 & From 6-10 & 4 & 36.4 \\
\hline$\geq 20$ years & 4 & 36.3 & 11 and more & 3 & 27.2 \\
\hline $\begin{array}{l}\text { 2-Obtaining environmental } \\
\text { management certificates: }\end{array}$ & & & $\begin{array}{l}\text { 6- The presence of an } \\
\text { environmental consultant: }\end{array}$ & & 18.2 \\
\hline Yes & - & - & Yes & 2 & 81.8 \\
\hline No & 11 & 100 & No & 9 & \\
\hline 3-Obtaining ISO certificates: & & & $\begin{array}{l}\text { 7- The presence of a quality } \\
\text { officer: }\end{array}$ & & 18.2 \\
\hline Yes & 1 & 9.1 & Yes & 2 & 81.8 \\
\hline No & 10 & 90.9 & No & 9 & \\
\hline \multicolumn{6}{|l|}{ 4-Obtaining other certificates: } \\
\hline Yes & 3 & 27.3 & & & \\
\hline No & 8 & 72.7 & & & \\
\hline
\end{tabular}


Table 2. Distribution of respondents according to the level of awareness of green practices

\begin{tabular}{|c|c|c|}
\hline Level of awareness & $\mathrm{N}=11$ & $\%$ \\
\hline Low (<51 degree $)$ & 5 & 45.5 \\
\hline Fair (from $51-<63$ degree) & 4 & 36.3 \\
\hline $\operatorname{High}(\geq 63$ degree $)$ & 2 & 18.2 \\
\hline
\end{tabular}

Table 3. Distribution of respondents according to the level of water green practices

\begin{tabular}{|c|c|c|}
\hline Level of water green practices & $\mathrm{N}=11$ & $\%$ \\
\hline Low $(<72$ degree $)$ & 1 & 9.1 \\
\hline Fair (from $72-<93$ degree) & 7 & 63.6 \\
\hline High ( $\geq 93$ degree) & 3 & 27.3 \\
\hline
\end{tabular}

\section{Energy green practices:}

Total level of energy green practices was distributed three categories according to the mean and standard deviation. Table (5) shows equal ratios to low and fair level (36.4), while $27.2 \%$ fell in the high level.

Table 5. Distribution of respondents according to the level of energy green practices

\begin{tabular}{lcc}
\hline \multicolumn{1}{c}{ Level of energy green practices } & $\mathbf{N}=\mathbf{1 1}$ & $\mathbf{\%}$ \\
\hline Low $(<20$ degree $)$ & 4 & 36.4 \\
Fair (from 20- $<36$ degree $)$ & 4 & 36.4 \\
High $(\geq 36$ degree $)$ & 3 & 27.2 \\
\hline
\end{tabular}

\section{Sustainable food and beverage practices:}

Total level of sustainable food and beverage practices was distributed among three categories according to the mean and standard deviation. Table (6) shows high ratio to fair level $(54.6 \%)$ while $27.3 \%, 18.2 \%$ fell in high and low levels respectively.

Table 6. Distribution of respondents according to the level of sustainable food and beverage practices

\begin{tabular}{lcc}
\hline $\begin{array}{c}\text { Level of sustainable food and } \\
\text { beverage practices }\end{array}$ & N=11 & \% \\
\hline Low $(<6$ degree $)$ & 2 & 18.2 \\
Fair (from 6- $<12$ degree $)$ & 6 & 54.6 \\
High $(\geq 12$ degree $)$ & 3 & 27.2 \\
\hline
\end{tabular}

\section{Total green practices:}

Total level of total green practices was distributed among three categories according to the mean and standard deviation. Table (7) shows that nearly half of the hotels were fair $(45.4 \%)$.
Table 7. Distribution of respondents according to the level of total green practices

\begin{tabular}{lcc}
\hline \multicolumn{1}{c}{ Level of total green practices } & N=11 & \% \\
\hline Low (less than 131 degree) & 3 & 27.3 \\
$\begin{array}{l}\text { Fair (from 131- less than 159 } \\
\text { degree) }\end{array}$ & 5 & 45.4 \\
High (159 degree and more) & 3 & 27.3 \\
\hline
\end{tabular}

Fourth: Motives for applying green practices in hotels:

Number of motives for applying green practices was distributed among three categories according to the mean and standard deviation. Table (8) shows that three quarters of the hotels were fair and few (45.5\%) (36.4\%) respectively, which means that there are five motives responsible for the hotel's compliance with green practices and they are in the following order of the highest proportion:

-Giving the hotel competitive advantages and improving its image and reputation.

- The right thing to do.

- Meet customers' desires.

- The hotel assumes its social responsibility.

-Conformity with governmental and international legislation and laws.

Table 8. Distribution of respondents according to number of motives

\begin{tabular}{lcc}
\hline \multicolumn{1}{c}{ Number of motives } & N=11 & \% \\
\hline Few $(<2)$ & 4 & 36.4 \\
Fair (From 2- <6) & 5 & 45.5 \\
Many $(\geq 6)$ & 2 & 18.2 \\
\hline
\end{tabular}

Fifth: Obstacles to applying green practices in hotels:

Number of obstacles for applying green practices was distributed among three categories according to the mean and standard deviation. Table (9) shows that $63.6 \%$ were few.This means that there are four obstacles 
facing the hotel's compliance with green practices and they are in the following order of the highest proportion:

- Lack of effective communication and lack of green programs between hotels.

- High costs of implementation and implementation.

- Lack of experience and knowledge.

- Difficulty dealing with green technology.

Table 9. Distribution of respondents according to number of obstacles

\begin{tabular}{lcc}
\hline \multicolumn{1}{c}{ Number of obstacles } & N=11 & \% \\
\hline Few (from 1-4 obstacle) & 7 & 63.6 \\
Fair (5-8 obstacle) & 2 & 18.2 \\
Many (9 and more) & 2 & 18.2 \\
\hline
\end{tabular}

The correlations between independent variables and green practices:

The first hypotheses states that: "There is no significant correlation between awareness and green practices applications in hotels related to some environmental resources including (water- solid waste energy - sustainable food and beverage) and characteristics of hotels under study".

So simple correlation coefficient was used to study the relationship between energy green practices as a dependent variable and each of level of the hotel according to number of stars for the hotel, the ISO certificates as independent variables and the value of the correlation coefficient was 0.602 .

This means that awareness about energy green practices increased as the level of the hotels is better which was confirmed by Mensah, I.(2006) who concluded that the largest guns (from 3-5 stars) were at the forefront of adopting and practicing environmental management practices.

While there was no correlation between awareness of green practices, water green practices, solid waste green practices, food and beverage green practices as dependent variables, and the number of stars and the number of ISO certificates as independent variables.

On the opposite of that Bagur, L. F. and others (2016) found in their study about environmental practices and hotels that adopt these certificates due to environmental pressure (from the government, customers and suppliers) and hotels that voluntarily commit to green polices, that hotels that voluntarily commit to green polices obtain better results than other hotels.

And by presenting the statistical results, the research hypothesis can be partly accepted and partially rejected.

\section{Impact relationships between independent variables and green practices:}

The Second hypotheses states that: "There is no influence relation between awareness and green practices applications in hotels related to some environmental resources including (water- solid waste energy - sustainable food and beverage) and characteristics of hotels under study".

So multiple regression function was used to determine the effect ratio between the properties of the hotel (number of stars - number of certificates) and green practices applied by the hotel. Table (11) shows no effect relationship between the number of stars and the number of certificates on each of (Y1 awareness of green practices, Y2 green practices for water, Y3 green practices for solid waste, and Y5 green practices for food and drinks),

Whereas, it greatly affected Y4 green energy practices, where the impact ratio was $36.2 \%$, and the value of $F(5.1)$ was at a significant level of 0.05 .

And by presenting the statistical results, the research hypothesis can be partly accepted and partially rejected.

Table 10. Correlations between independent variables and green practices

\begin{tabular}{lc}
\multicolumn{1}{c}{ Variable } & hotel characteristics \\
\hline Awareness of green practices and the impact of tourism on the & 0.115 \\
environment (y1) & \multicolumn{2}{c}{-0.019} \\
Level of water practices (y2) & -0.159 \\
Green practices for solid wastes and residues (y3) & $0.602^{*}$ \\
Green Energy Practices (y4)* & 0.181 \\
Sustainable Food \& Beverage Practices (y5) & 0.307 \\
Total practices (y6) & \\
\hline
\end{tabular}

*significant at level 0.05 
Table 11. Impact relationships between independent variables and green practices

\begin{tabular}{|c|c|c|c|c|c|c|c|}
\hline $\begin{array}{l}\text { Dependent } \\
\text { variable }\end{array}$ & & $\begin{array}{c}\text { Y1 } \\
\text { Awareness } \\
\text { of green } \\
\text { practices }\end{array}$ & $\begin{array}{c}\text { Y2 } \\
\text { Green } \\
\text { practices } \\
\text { for water }\end{array}$ & $\begin{array}{c}\text { Y3 } \\
\text { Green } \\
\text { practices } \\
\text { for solid } \\
\text { waste }\end{array}$ & $\begin{array}{c}\text { Y4 } \\
\text { Green } \\
\text { energy } \\
\text { practices }\end{array}$ & $\begin{array}{c}\text { Y5 } \\
\text { Green } \\
\text { practices for } \\
\text { food and } \\
\text { drinks }\end{array}$ & $\begin{array}{c}\text { Y6 } \\
\text { Total } \\
\text { green } \\
\text { practices }\end{array}$ \\
\hline $\begin{array}{r}\text { Independent } \\
\text { variable }\end{array}$ & & & & & & & \\
\hline $\begin{array}{l}\text { The total } \\
\text { number of stars }\end{array}$ & $\begin{array}{l}\text { Impact } \\
\text { ratio \% }\end{array}$ & 1.3 & - & 2.5 & 36.2 & 3.3 & 9.4 \\
\hline $\begin{array}{l}\text { and the number } \\
\text { of ISO } \\
\text { certificates }\end{array}$ & $\begin{array}{l}\text { Value } \\
\text { of }(F)\end{array}$ & 0.12 & 0.03 & 0.234 & 5.1* & 0.303 & 0.934 \\
\hline
\end{tabular}

* significant at level 0.05

\section{Recommendations}

The following recommendations were based on the findings of the study:

- Encourage hotel owners to adopt sustainable environmental practices, reducing dependence on traditional energy and hold international conferences to develop tourism especially in siwa as it is an important tourist area in Egypt, attractive to tourists who love green environmental life.

- Raising awareness about the importance of good practices towards the environment, especially for hotel managers.

- Conducting informational sessions for hotel owners and employees on preserving the surrounding environment.

- Inviting the relevant ministries to provide environmentally friendly facilities and equipment.

- Encourage hotel guests to adopt rational environmental practices.

- Ministry of tourism should form a standard framework for required green practices similar to the ISO framework.

- Future studies can be conducted in other touristic places.

\section{REFERENCES}

Bagur, L. F., D. Celma, and J. Patau. 2016. The Adoption of Environmental Practices in Small Hotels. Voluntary or Mandatory? An Empirical Approach, Sustainability 2016, 8, 695; doi: 10.3390/su8070695, www.mdpi.com/journal/sustainability.

Barakat, M. 2016. Sustainability of UNDP projects in Egypt: A case study in siwa oasis, j.Agric.Res.Kafr El-Sheikh Univ. 42 (2).pp: 382-393.
Cerin,P.2006. Bringing economic opportunity into line with environmental influence: A Discussion on the Coase theorem and the Porter and van der Linde hypothesis. Ecological Economics, 209-225.

El demerdash, A. 2018. Ecotourism in Siwa Oasis, Journal of Scientific Research in Literature. 19 (9) pp:1-20.

Erdogan, N. 2007.Environmental protection programs and conservation practices of hotels in Ankara, Turkey, Tourism Management, vol.28.2.

GHA. 2009. "What are Green Hotels?" Available at:http:// www.greenhotels.com

Hamad, A. E. (2015): Promoting the concept of green practices in the hotels sector to ensure sustainable tourism development: a case study of the hotels in the Gaza Strip, Journal of the Islamic University for Humanitarian Research.23. 1. pp: 261-294,.

Han, H. and Kim, Y. (2010), “An investigation of green hotel customers' decision formation: Developing an extended model of the theory of planned behavior", International Journal of Hospitality Management, Vol 29, No 4, pp.659-668.

Ijasan, K., O. Ajibola and K. Gaibee.2016. The case for green hotels: an investigation into the outlook of South African business travelers, International journal of applied environmental sciences, vol.11, No 3, pp: 809-824.

Leal Londono, M. P. and G. Hernandez-Maskivker. 2016. Green practices in hotels: the case of the greenleaders program from Tripadvisor, $7^{\text {th }}$ international conference on sustainable tourism.www.witconferences.com

Manaktola, K. and V. Jauhari. 2007. "Exploring consumer attitude and behaviour towards green practices in the lodging industry in India", International Journal of Contemporary Hospitality Management, Vol 19, No 5., pp:364-377.

Mensah, I. 2006. Environmental management practices among hotels in the greater Accra region, International journal of hospitality management, vol.25,3. 
Neeti K., A. Srishti. 2015.A study on consumer's choice of preference for the green attributes of the hotel industry, international conference on evidence based management (ICEBM2015).

https://www.researchgate.net/publication/318461258

Norazah, M. S. and M. S. Norbayah. 2015. "Consumers' environmental behavior towards staying at a green hotel: Moderation of green hotel knowledge", Management of Environmental Quality, Vol. 26. 1, pp.103117.https://doi.org/10.1108/MEQ-02-2014-0023

Raslan, A. A., M. A. Morse, H. E. Saad and M. El-Husseiny. 2016.Evaluation study for sustainable development in hotels in some tourist areas in Egypt, journal of faculty of tourism and hotels, fayoum university, vol.10, No.(2/2).

Sameh, A. and A. Elsayed. 2013.A study on green hotels in Egypt, Journal of the Union of Arab Universities for Tourism and Hospitality, vol.10, No. (1), pp.159-172.

Zwena, B. F. 2009.Green hotels are one of the entry points to achieve sustainable development, a scientific paper presented to the school day, Tourism development and its role in tourism development, part 1, Ministry of Urban Development - Environment and Tourism, 21 December, Algeria.

\section{Attachments}

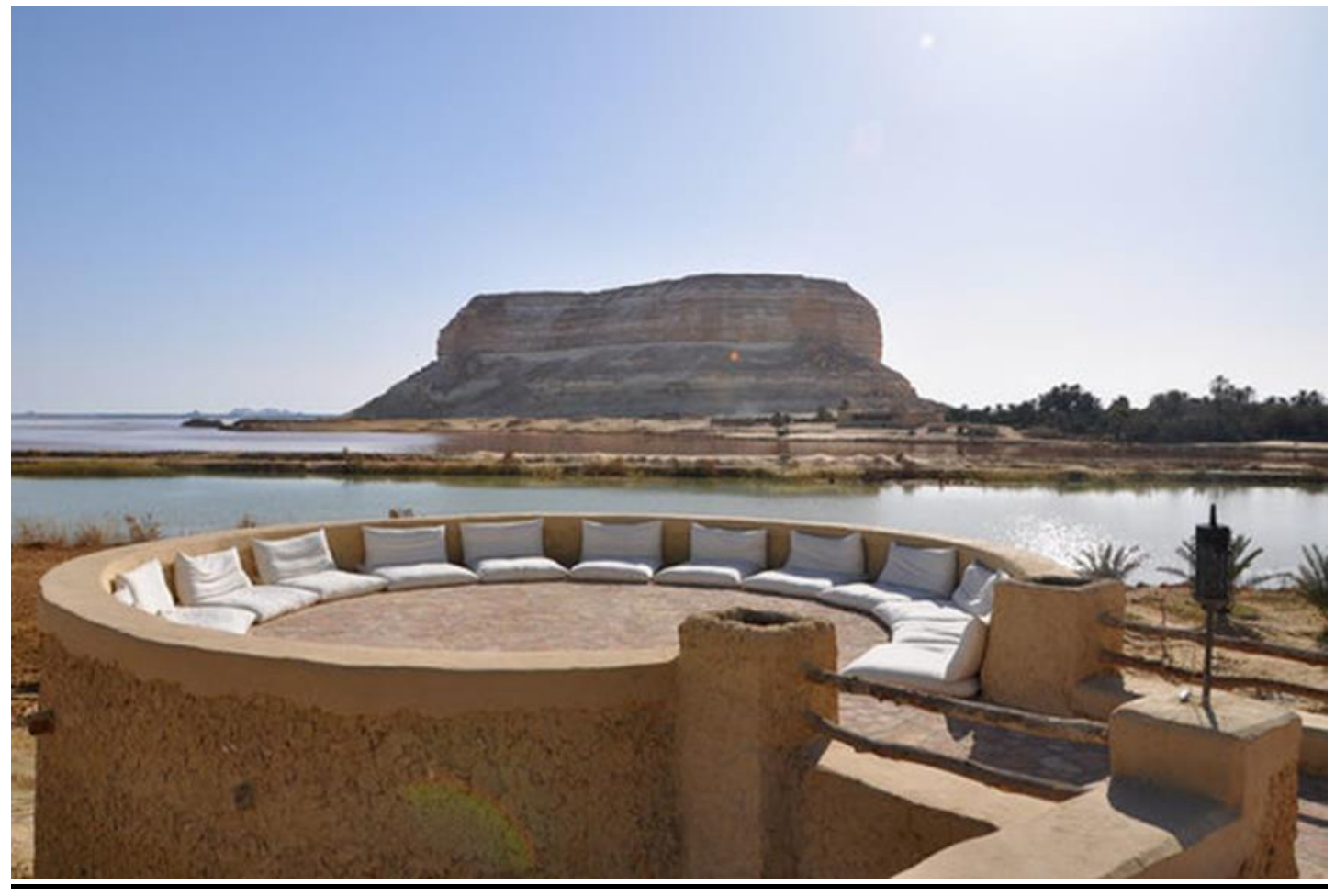



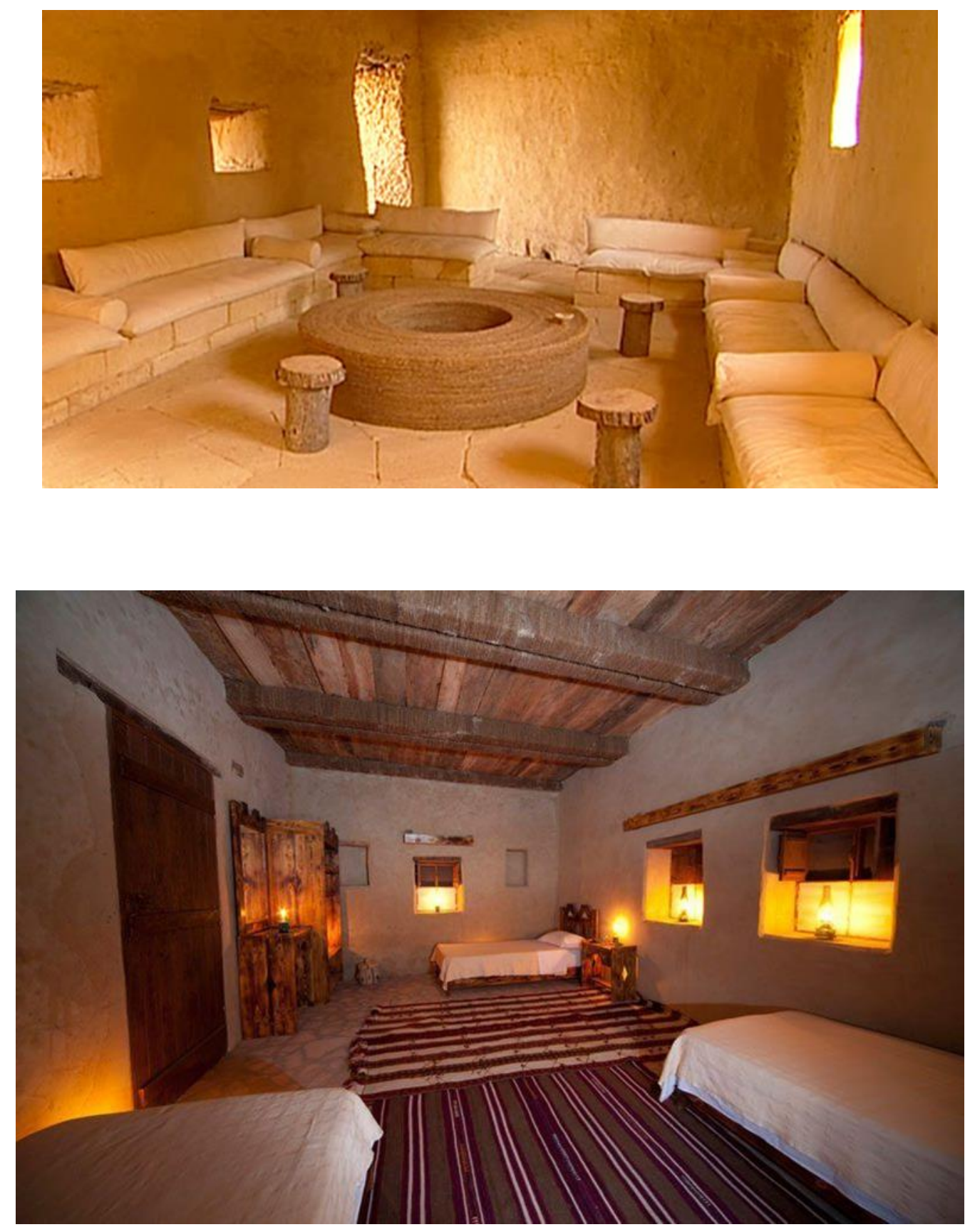

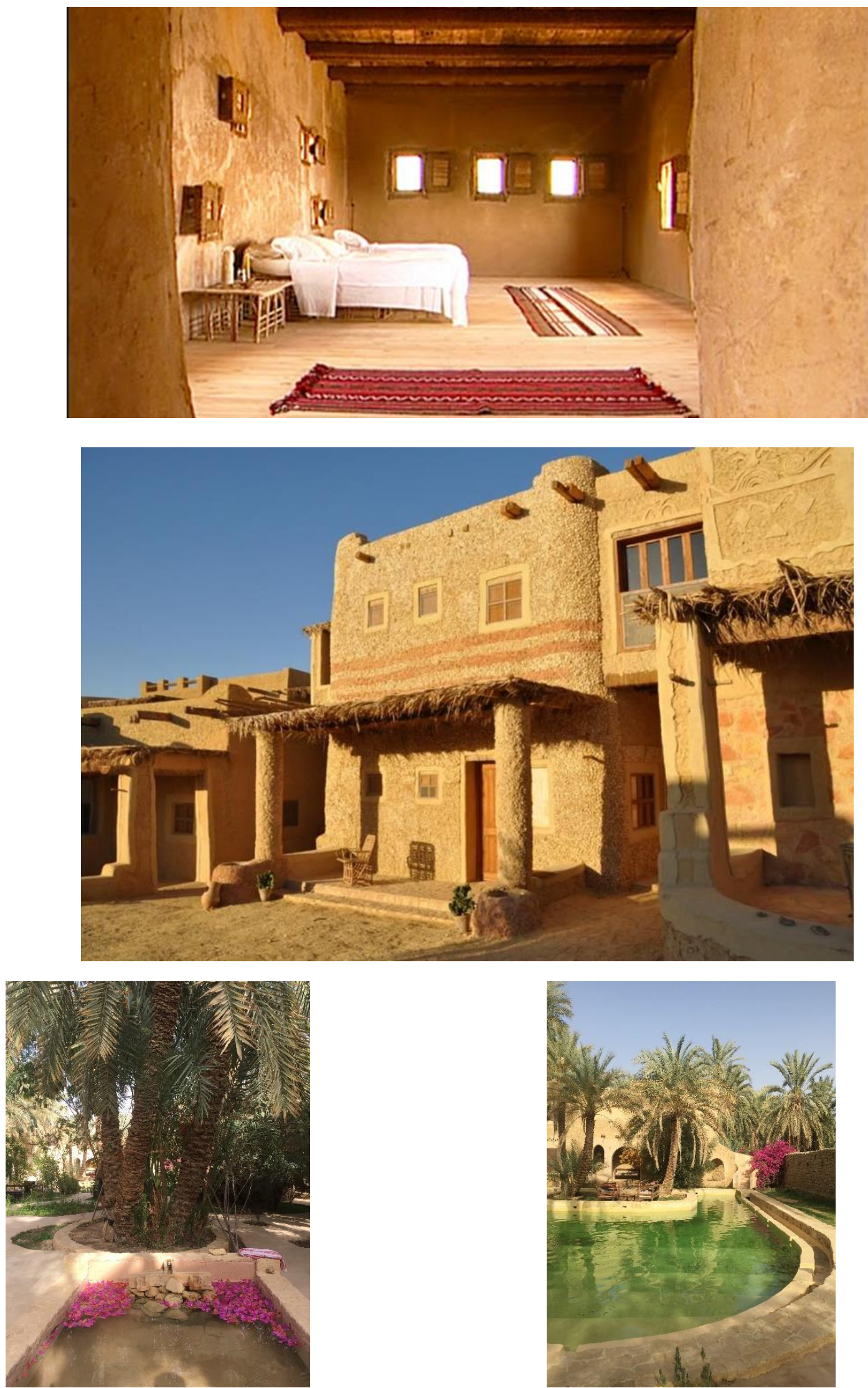

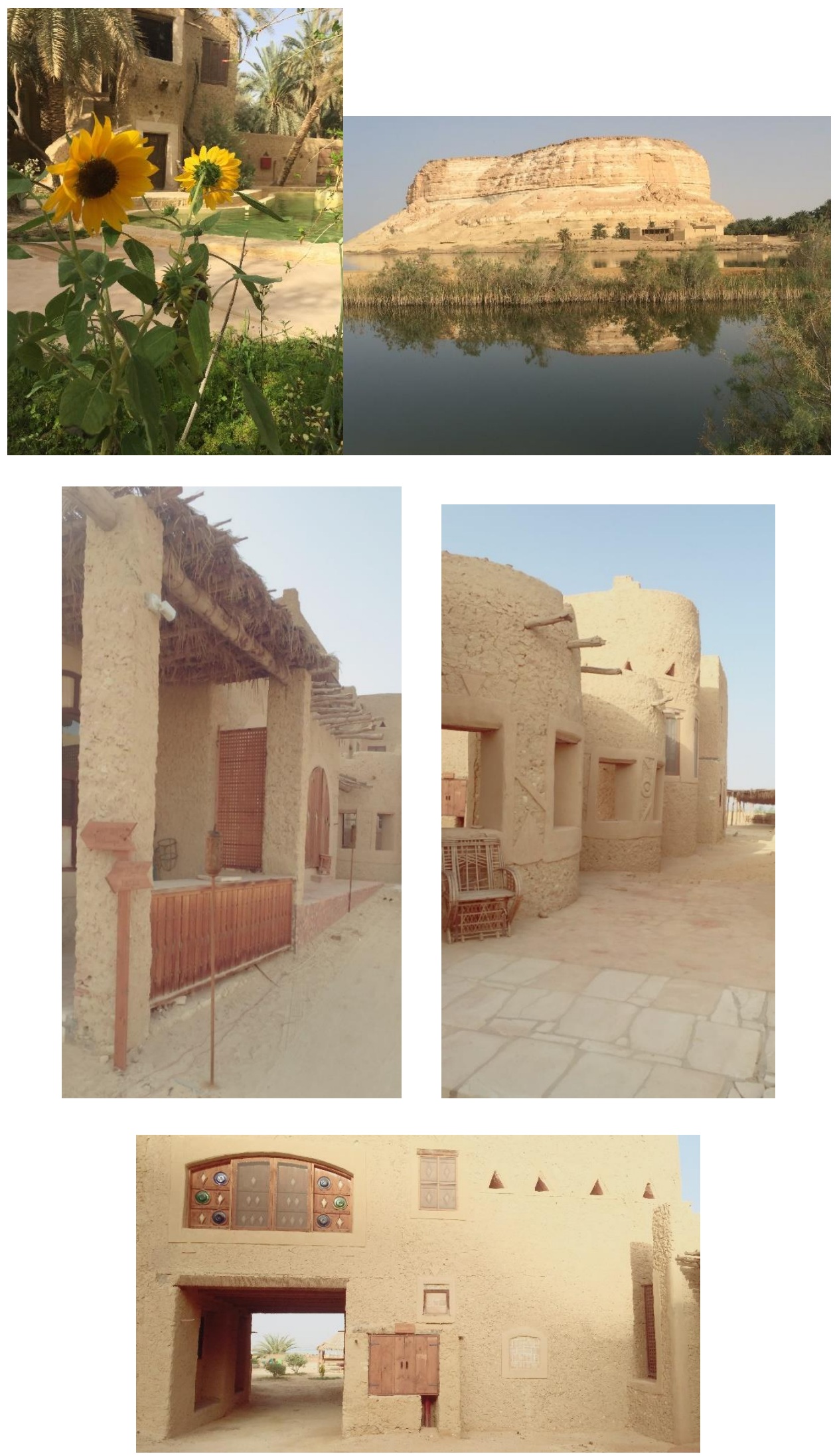

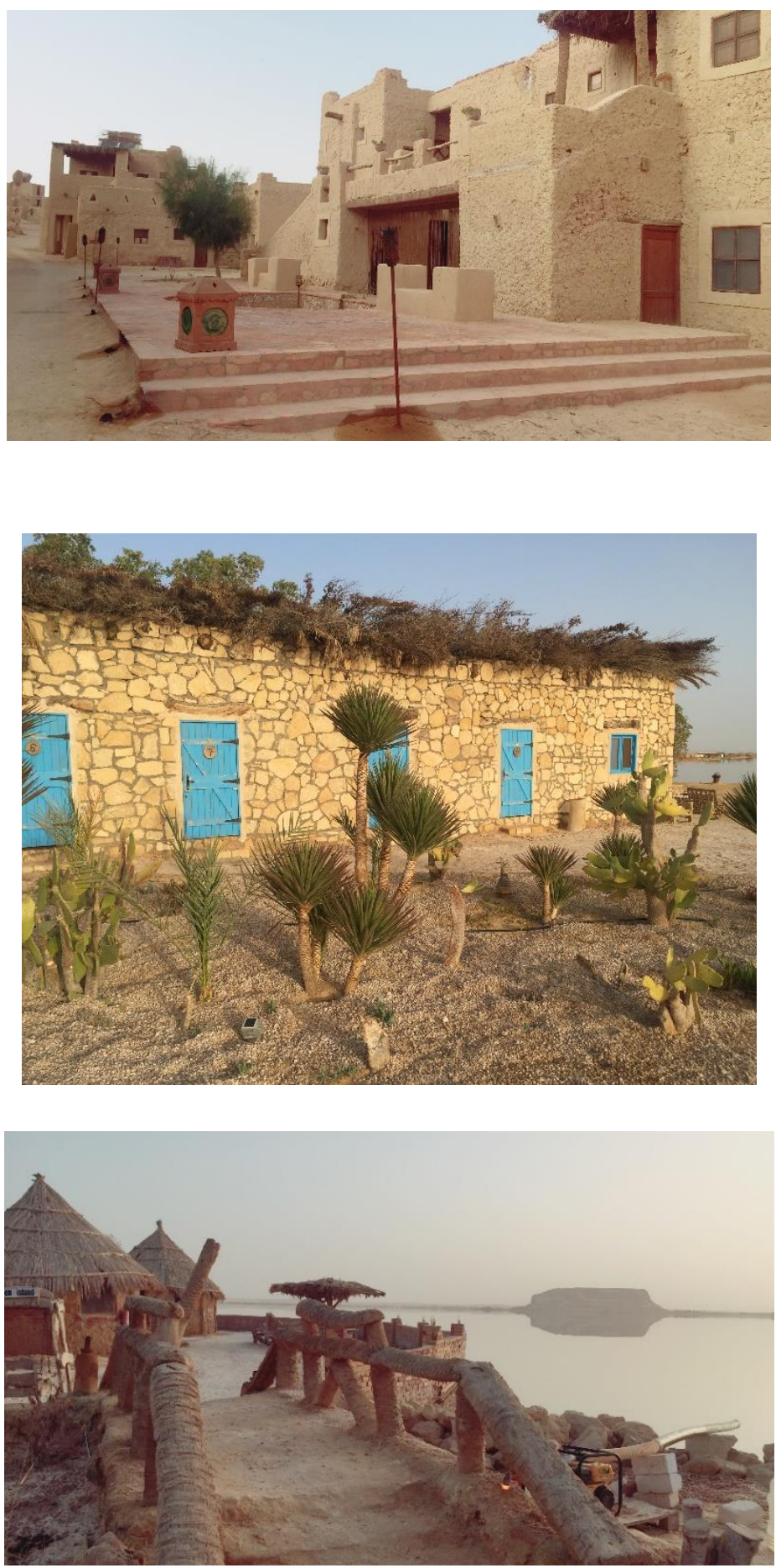


\section{الملخص العربي \\ تطبيق الممارسات الخضراء فى القطاع الفندقى لضمان التنمية المستدامة دراسة حالة الفنادق فى واحة سيوة}

$$
\text { آية سمير أحمد سالم }
$$

إجمالي ·r ف فندق في واحة سيوة بالإضافة إلى دراسة حالة

$$
\text { الفنادق وإجراء التصوير الفوتوغرافى لها. }
$$

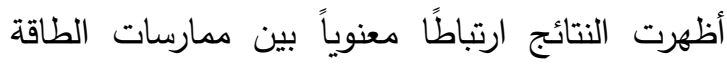
الخضراء كمتغير تابع وبين إجمالي عدد نجوم الفنادق

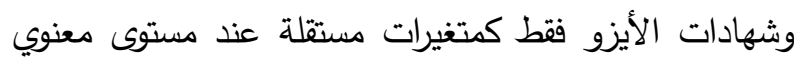

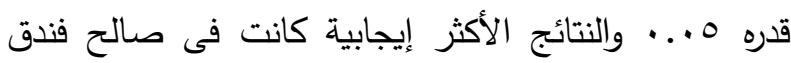

$$
\text { تازيرى إيكولودج. }
$$

وهذه النتائج تدعم تطبيق نظم الممارسات الخضراء فى

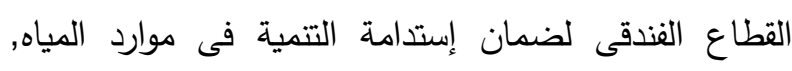
الطاقة, المخلفات الصلبة والغذاء.
يعد القطاع الفندقى من أهم العوامل التى تئثر فى القى

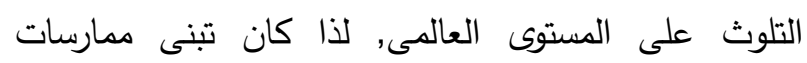

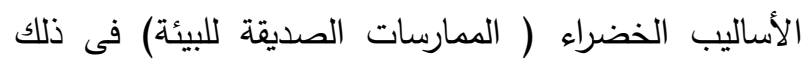

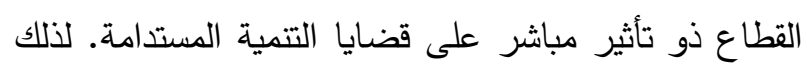
يهذف هذا البحث إلى تسليط الضوء على الممارسات الخضراء في فنادق سيوة وعلاقتها بالتتمية المستدامة. تم تجميع البيانات من خلال استمارة استبيان بالمقابلة الثخصية مع مديري الفنادق لعدد 11 فندق تم إختيارهم

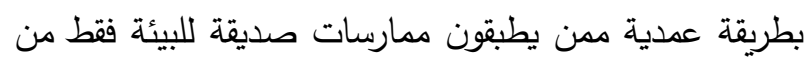

